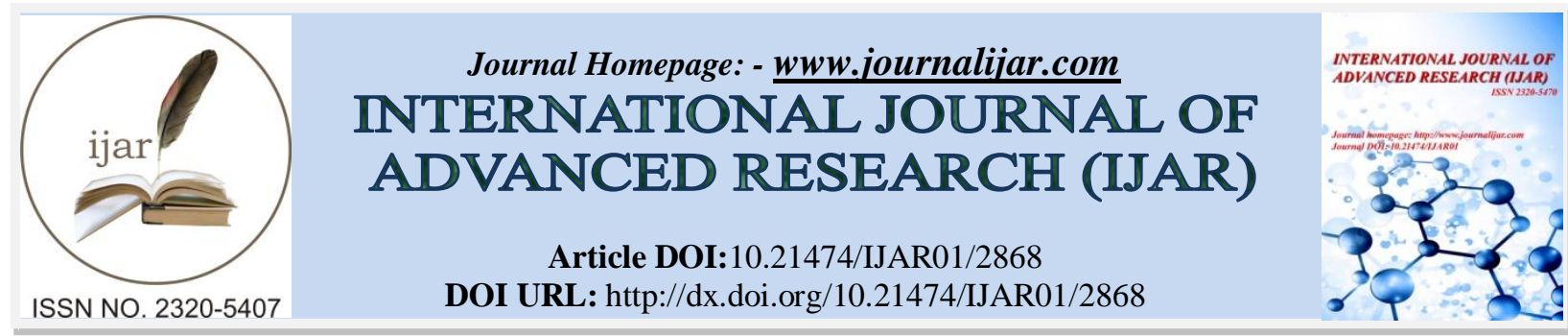

RESEARCH ARTICLE

\title{
BACTERIAL CONTAMINATION OF HEALTHCARE WORKERS' MOBILE PHONES IN A TERTIARY CARE CENTER IN SAUDI ARABIA
}

\author{
Fares Almeshal ${ }^{1}$, Feras Asiri ${ }^{1}$, Anas Alyamani ${ }^{1}$, Mohammed Altuwaijri ${ }^{1}$, Sameera Aljehani ${ }^{1,2,4}$, Abdulhai \\ Almuhana $^{2}$ and Adel Alothman ${ }^{1,3,4}$. \\ 1. College of Medicine, KSAU-HS, Riyadh \\ 2. Department of microbiology, KAMC-Riyadh \\ 3. Division of infectious diseases, KAMC-Riyadh \\ 4. King Abdullah International Research Center," KAIMRC" Riyadh
}

\section{Manuscript Info}

Manuscript History

Received: $x x x x x x x x x x x x x x x x$

Final Accepted: $x x x x x x x x x x x x$

Published: $\mathrm{xxxxxxxxxxxxxxxx}$

Key words:-

Bacterial contamination, mobile phones, Saudi Arabia

\section{Abstract}

Background: Mobile phones provide health care workers' (HCWs) with fast communication and quick access to medical information. Their frequent use in the hospital environment may pose a risk of spreading nosocomial infections. In this study, we aimed to determine the bacterial contamination of HCWs' mobile phones.

Materials/Methods: Samples were collected from mobiles of HCWs' atKing Abdulaziz Medical City, Riyadh. A swab takenfrom the mobile phone and a questionnaire was answered by each subject. The swabs were sent to the lab for culture, carrying a serial number to indicate the questionnaire.

Results: Of the 400 mobile phone samples, 171 (43\%) showed bacterial growth. Different variables were examined. The number of male HCWs sampled was 167,90 of them $(54 \%)$ showed positive growth, while only $81(35 \%)$ of the 233 samples taken from female participants showed positive growth ( $\mathrm{p}$-value $=<0.005$ ). In addition, samples taken from phones that are frequently cleaned (226 samples) showed $10 \%$ less growth than mobile phones that are not frequently cleaned $(\mathrm{p}$-value $=0.049)$. The most commonly isolated organism was Coagulase negative Staphylococci, which were isolated from $121(30 \%)$ phones of the mobile phones sampled.

Discussion: More than one third of the HCWs' mobile phones were contaminated with bacteria. Our results showed that the degree of bacterial contamination in KAMC-Riyadh is less than studies done in other countries. The most common isolated organism in many of the reviewed studies was methicillin sensitive S.aureus, while in our study it was coagulase negative Staphylococci.

Conclusion:More than one third of the HCWs mobile phones were contaminated by bacteria. The results support the claim that HCWs' mobile phones may serve as vectors for transmission of nosocomial infections, and that cleaning mobile phones may reduce this risk. 
Copy Right, IJAR, 2016,. All rights reserved.

\section{Introduction:-}

Mobile phones provide healthcare workers (HCWs) with faster communication and quick access to information, hence, they are usually kept near-at-hand. ${ }^{7}$ Some hospitals are even using mobile phones instead of pagers. ${ }^{9,10}$ There are currently no guidelines on mobile phone cleaning and handling in the medical field. Whenever HCWs use their mobile phones, they may transmit organisms from their hands to their mobile phones. As a result, HCWs' mobile phones serve as reservoirs for these microorganisms that could be easily transmitted back to the HCWs' hands. In this way, mobile phones may facilitate the transmission of nosocomial infections.

Many studies have supported this claim: a study done in Turkey has shown that $94 \%$ of HCWs' mobile phones and hands in operating rooms and intensive care units demonstrated evidence of bacterial contamination with different types of bacterial organisms. $31.3 \%$ of the mobile phones sampled were contaminated with gram negative strains. ${ }^{11}$ Another study done in India has shown that as much as $98.5 \%$ of HCWs' mobile phones were contaminated by bacteria. ${ }^{12}$ Furthermore, a study that sampled 90 HCWs' mobile phones revealed that $70(89.7 \%)$ mobile phones were contaminated by bacteria, 10 of them $(11.5 \%)$ were contaminated with bacteria known to cause nosocomial infections. ${ }^{15}$

Our study was conducted in King Abdulaziz Medical City (KAMC)-Riyadh. KAMC-Riyadh is a 962 bed tertiary care center located in Riyadh City, Saudi Arabia, which is affiliated with King Saud Bin Abdul-Aziz University for Health Sciences. ${ }^{16}$ In this study, we aimed to determine the degree of bacterial contamination of HCWs' mobile phones in KAMC-Riyadh and to identify the microorganisms colonizing these mobile phones. Also, we wanted to estimate the effect of various factors (e.g. gender, position, department of the owner and age of the mobile phone) on bacterial contamination of the mobile phones.

\section{Methods:-}

A total of 400 samples were collected from HCWs. Non-probability convenience sampling was used. Each morning the principal investigator would assign the data collectors to a different location inside the hospital. Ten samples were collected per day. Before taking samples, written consent was taken from each participant. After that, the participant's mobile phone was sampled using a sterile wet swab. All 400 swab-samples were collected by a single data collector to ensure consistency of the swabbing technique. The back and sides of the mobile phone were swabbed using a sterile wet swab. Simultaneously, the participant was asked to fill a questionnaire. The questionnaire was prepared based on literature review. The questionnaire assessed the following factors: position, department, gender, years of owning the mobile phone, frequency and method of cleaning the phone,frequency of usage of the mobile phone,use of headphones, and use of the phone while dealing with patients. Then, the swabs were taken to the lab conservatively, and assigned lab technicians cultured the samples on blood agar media for 48 hours. Positive cultures were further analyzed using Gram stain, Coagulase, and Catalase reactions. ${ }^{11,12,14,15}$

After obtaining culture results, data from the lab and questionnaire were entered into Microsoft Excel. After data entry was done, data was exported to SPSS version 21 for analysis. Variables were analyzed by Chi square test. P values $<0.05$ were considered significant.

\section{Results:-}

The rate of bacterial contamination of HCWs' mobile phones was 43\% (171 phones). Coagulase negative Staphylococci were isolated from 123 (30\%) mobile phones, followed by Corynebacterium species, which was isolated from $53(13 \%)$ mobile phones. Details of the number and type of bacteria obtained from mobile phones are depicted in Figure I. 


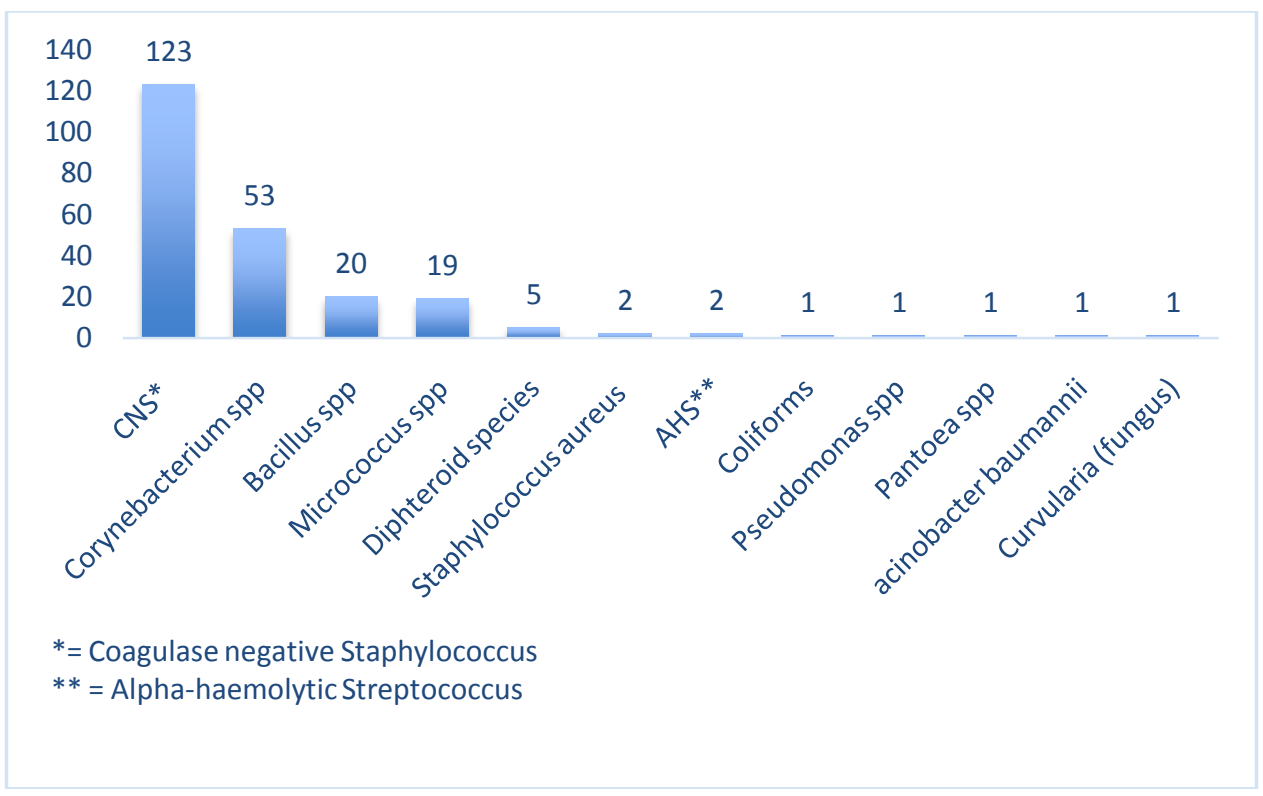

Figure I-Frequency of isolated organisms from mobile phones

Demographic variables and their effect on phone contamination were obtained from HCWs and are summarized in Table 1. Phone related factors and whether or not they affected the rate of contamination are shown in Table 2. Of the aforementioned variables, only two showed significant difference, which were gender of the owner and cleaning the mobile phone. The number of samples taken from male participants was 167, of which 90 samples(54\%) showed positive growth. On the other hand, $81(35 \%)$ of the 233 samples taken from female participants showed positive growth ( $\mathrm{p}$-value $=<0.005$ ). In addition, samples taken from phones that are cleaned daily ( 226 samples) showed $10 \%$ less growth than mobile phones that are not cleaned daily ( $\mathrm{p}$-value $=0.049$ ). In addition to isolating various bacteria, one mobile phone of a female nurse isolated a fungus "Curvularia species."

Table 1:- Participant demographics.

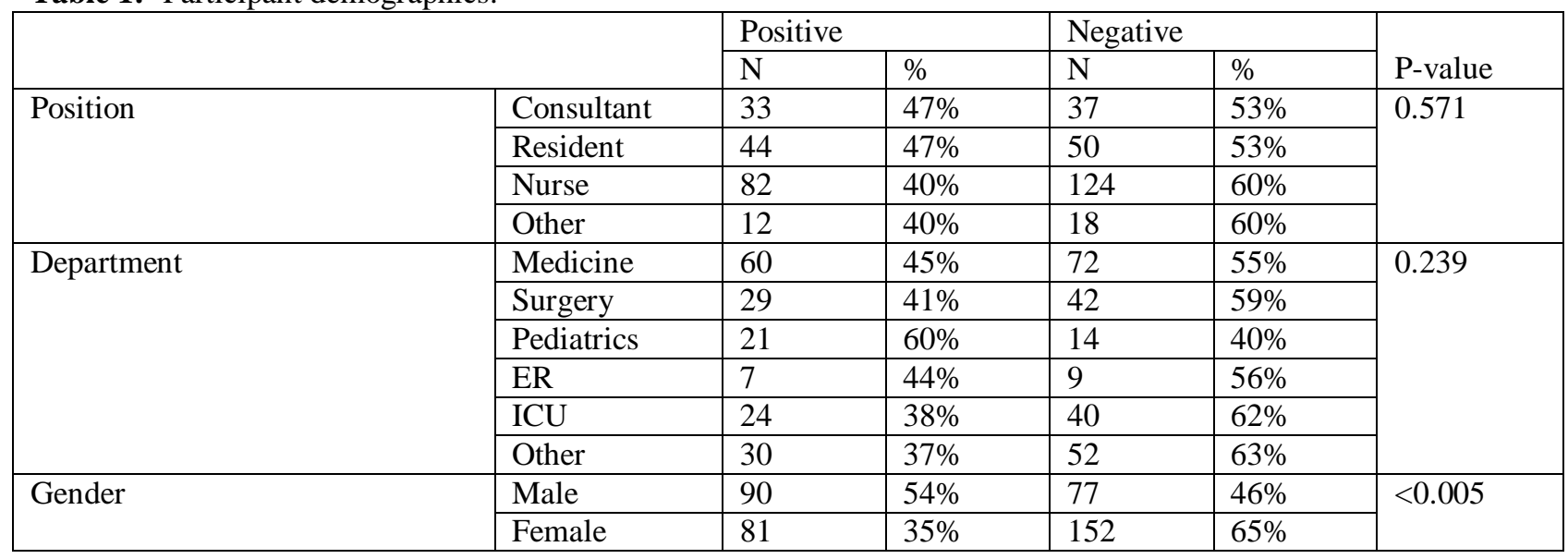


Table 2:- Phone related factors.

\begin{tabular}{|c|c|c|c|c|c|c|}
\hline & & \multicolumn{2}{|c|}{ Positive } & \multicolumn{2}{|c|}{ Negative } & \multirow[b]{2}{*}{ P-value } \\
\hline & & $\mathrm{N}$ & $\%$ & $\mathrm{~N}$ & $\%$ & \\
\hline \multirow[t]{4}{*}{ Age of your cell phone } & $<6$ months & 59 & $67 \%$ & 29 & $33 \%$ & \multirow[t]{4}{*}{0.190} \\
\hline & 6-12 months & 53 & $57 \%$ & 40 & $43 \%$ & \\
\hline & 13-24 months & 54 & $53 \%$ & 47 & $47 \%$ & \\
\hline & $>24$ months & 63 & $53 \%$ & 55 & $47 \%$ & \\
\hline \multirow{5}{*}{$\begin{array}{l}\text { How many times do you clean } \\
\text { your cell phone per day? }\end{array}$} & 0 & 90 & $52 \%$ & 84 & $48 \%$ & \multirow[t]{5}{*}{0.396} \\
\hline & 1 & 92 & $61 \%$ & 59 & $39 \%$ & \\
\hline & 2 & 26 & $62 \%$ & 16 & $38 \%$ & \\
\hline & 3 & 12 & $67 \%$ & 6 & $33 \%$ & \\
\hline & 4 or more & 9 & $60 \%$ & 6 & $40 \%$ & \\
\hline \multirow[t]{2}{*}{ Do you clean your mobile phone? } & Yes & 139 & $62 \%$ & 87 & $38 \%$ & \multirow[t]{2}{*}{0.04998} \\
\hline & No & 90 & $52 \%$ & 84 & $48 \%$ & \\
\hline \multirow{4}{*}{$\begin{array}{l}\text { How many times do you use your } \\
\text { cellphone during working hours? }\end{array}$} & $>15$ & 76 & $60 \%$ & 50 & $40 \%$ & \multirow[t]{4}{*}{0.384} \\
\hline & $10-15$ & 44 & $59 \%$ & 31 & $41 \%$ & \\
\hline & $5-9$ & 52 & $60 \%$ & 34 & $40 \%$ & \\
\hline & $<5$ & 57 & $50 \%$ & 56 & $50 \%$ & \\
\hline \multirow[t]{2}{*}{ Do you use headphones? } & Yes & 85 & $59 \%$ & 58 & $41 \%$ & \multirow[t]{2}{*}{0.509} \\
\hline & No & 144 & $56 \%$ & 113 & $44 \%$ & \\
\hline \multirow{2}{*}{$\begin{array}{l}\text { Do you use your cellphone while } \\
\text { dealing with the patient? }\end{array}$} & Yes & 62 & $52 \%$ & 58 & $48 \%$ & \multirow[t]{2}{*}{0.139} \\
\hline & No & 167 & $60 \%$ & 113 & $40 \%$ & \\
\hline
\end{tabular}

\section{Discussion:-}

Of the phones sampled in this current study, $43 \%$ showed positive bacterial growth which is comparable to a study conducted in the eastern province of Saudi Arabia by Sadat-Ali et al.. ${ }^{17}$ Most studies show higher contamination rate than our study. Another study done by Ulger et al. reported that $94.5 \%$ of 200 health care workers' mobile phones were contaminated with various microorganisms, including nosocomial pathogens. ${ }^{11}$ Another study done in India has shown that as much as $98.5 \%$ of HCWs' mobile phones were bacterially contaminated. ${ }^{12}$ However, a study done in Queen Elizabeth hospital in Barbados, West Indies, had results similar to ours with $45 \%$ of mobile phones of 266 medical staff and students were culture positive. ${ }^{14}$

In our study, the most frequently isolated organism was coagulase negative Staphylococcus which was isolated from $30 \%$ (121 phones) of the samples. The most common organisms found by Sadat-Ali et al. were Staphylococcus aureus (33\%), followed by Staphylococcus epidermidis $(22.9 \%)$ and Escherichia coli $(12.8 \%)$. ${ }^{17}$ Whereas, a study done in Egypt by Badr et al. had similar results to our study with coagulase negative Staphylococcus being the most common isolated organism (33.3\%). ${ }^{18}$ Also, $90.5 \%$ of the phones sampled by Ulger et al. showed positive growth of coagulase negative Staphylococcus. ${ }^{11}$

The fact that we were able to isolate a fungus "Curvalaria species" indicates another area of thinking about the chance that mobile phones can transmit fungal infections to certain patients.

A limitation to our study is the lack of antibiotic sensitivity testing, which prevented us from accurately comparing our results to other studies. Also, we were not able to assess the risk of some of the isolated bacteria.

Even though the use of cellphones may facilitate patient care, it may pose a risk to patients in the form of transmitting nosocomial infections. Cleaning mobile phones reduces the bacterial contamination of mobile phones which may decrease this risk. We recommend that mobile phone cleaning guidelines are put forth and implemented. Furthermore, the use of mobile phones should be restricted in high-risk situations. 


\section{References:-}

1. Balkhy HH, Cunningham G, Chew F, Francis C, Al Nakhli DJ, Almuneef MA et al. Hospital- and communityacquired infections: a point prevalence and risk factors survey in a tertiary care center in Saudi Arabia. Int J Infect Dis 2006; 10(4):326-33.

2. Ortona L, Federico G, Fantoni M, Ardito F, Branca G, Caponera S, et al. A study on the incidence of nosocomial infections in a large university hospital. Eur J Epidemiol. 1985; 1(2):94-99.

3. Klevens RM, Edwards JR, Richards CL, Horan Tc, GaynesRp, Pollock Da et al. Estimating Health CareAssociated Infections and Deaths in U.S. Hospitals, 2002. Public Health Rep 2007; 122(2):160-6.

4. Alothman AF, Jelani A, Althaqafi A, Rich M, Williams E. Contamination of patient hospital charts by -bacteria. J Hosp Infect. 2003; 55(4):304-305.

5. Alothman AF, Bukhari A, Maimony $\mathrm{H}, \mathrm{Al}$ Johani $\mathrm{S}$, Muhanna A. What is the role of stethoscope in transmitting infection at a tertiary care saudi center? Int J Infect Dis. 2008; 12(1):350.

6. Mayhall CG Hospital epidemiology and infection control, 4th ed. Philadelphia : Lippincott Williams \&Willkins; 2012.

7. Cisco. Hospital increases efficiency of mobile clinicians and staff. [homepage on the Internet]. 2012 [cited 2013 Sep 26]. Available from: http://www.cisco.com/en/US/prod/collateral/voicesw/evergreen_hospital.pdf

8. Brady RR, Wasson A, Stirling I, Mcallister C, Damani NN. Is your phone bugged? The incidence of bacteria known to cause nosocomial infection on healthcare workers' mobile phones. J Hosp Infect. 2006 Jan; 62(1):123125.

9. Dolan B. 72 percent of US physicians use smartphones. [homepage on the Internet]. May 5, 2010 [cited 2013 Sep 26]. Available from: http://mobihealthnews.com/7505/72-percent-of-us-physicians-use-smartphones

10. Bhanoo SN. Doctors and medical students embrace smartphones. [homepage on the Internet]. May 19, 2009 [cited 2013 Sep 26]. Available from: http://www.washingtonpost.com/wpdyn/content/article/2009/05/18/AR2009051802234.htm

11. Ulger F, Esen S, Dilek A, Yanik K, Gunaydin M, Leblebicioglu H. Are we aware how contaminated our mobile phones with nosocomial pathogens? Ann ClinMicrobiolAntimicrob 2009 Mar; 8:7 doi:10.1186/1476-0711-8-7.

12. Sham SB, Sundeep HK, Shailaja S. Potential of mobile phones to serve as a reservoir in spread of nosocomial pathogens. J Hosp Infect. 2011 Jun; 10(2). Available from: http://www.ojhas.org/issue38/2011-2-14.htm

13. Jeske HC, Tiefenthaler W, Hohlrieder M, Hinterberger G, Benzer A. Bacterial contamination of anaesthetists' hands by personal mobile phone and fixed phone use in the operating theatre. Anaesthesia. 2007; 62(9):904906.

14. Ramesh J, Carter AO, Campbell MH, Gibbons N, Powlett C, Moseley H SR, et al. Use of mobile phones by medical staff at Queen Elizabeth Hospital, Barbados: evidence for both benefit and harm. J Hosp Infect. 2008 Oct; 70(2):160-165.

15. Brady RR, Fraser SF, Dunlop MG, Paterson-brown S, Gibb A. Bacterial contamination of mobile communication devices in the operative environment. J Hosp Infect. 2007 Aug; 66(4):397-398.

16. KAMC. King Abdulaziz Medical City - Riyadh. [homepage on the Internet]. Jun 2013 [cited 2013 Oct 3]. Available from: National Guard Health Affairs, Web site: http://www.ngha.med.sa/ENGLISH/MEDICALCITIES/AlRiyadh/Pages/default.asp

17. Sadat-Ali M, Al-Omran AK, Azam Q, Bukari H, Al-Zahrani AJ, Al-Turki RA, Al-Omran AS. Bacterial flora on cell phones of health care providers in a teaching institution. American journal of infection control. 2010 Jun 30;38(5):404-5.

18. Badr RI, ibrahimBadr H, Ali NM. Mobile phones and nosocomial infections. International Journal of Infection Control. 2012 Mar 26;8(2). 